\title{
Reconstruction of the salinity history associated with movements of mangrove fishes using otolith oxygen isotopic analysis
}

\author{
Kotaro Shirai ${ }^{1, *}$, Futa Koyama ${ }^{2}$, Naoko Murakami-Sugihara1, Kusuto Nanjo ${ }^{3}$, \\ Tomihiko Higuchi ${ }^{1}$, Hiroyoshi Kohno ${ }^{4}$, Yoshiro Watanabe ${ }^{1}$, Ken Okamoto ${ }^{2}$, \\ Mitsuhiko Sano ${ }^{2}$
}

\footnotetext{
${ }^{1}$ Atmosphere and Ocean Research Institute, The University of Tokyo, Kashiwanoha, Kashiwa, Chiba 277-8564, Japan

${ }^{2}$ Department of Ecosystem Studies, Graduate School of Agricultural and Life Sciences, The University of Tokyo, Yayoi, Bunkyo, Tokyo 113-8657, Japan
}

${ }^{3}$ Department of Applied Aquabiology, National Fisheries University, Nagata-honmachi, Shimonoseki, Yamaguchi 759-6595, Japan ${ }^{4}$ Okinawa Regional Research Center, Tokai University, Uehara, Taketomi, Okinawa 907-1541, Japan

\begin{abstract}
Recent degradation and loss of tropical estuaries due to human impact have made necessary the protection of essential habitats for estuarine fishes. A better understanding of estuarine use patterns contributes greatly to identifying essential habitat conditions. This study presents quantitative reconstruction data of the salinity history experienced by individual estuarine fishes using an otolith oxygen isotope. $\delta^{18} \mathrm{O}_{\text {otolith }}$ was determined from the kuhliid Kuhlia rupestris and pomacentrid Chrysiptera cyanea for use as freshwater and marine end-member references, respectively. The salinity histories of 3 species of estuarine mangrove fishes, often dominant in tropical East Asian estuaries, viz. the apogonid Fibramia amboinensis, the pomacentrid Neopomacentrus taeniurus and the terapontid Terapon jarbua, were examined. The $\delta^{18} \mathrm{O}_{\text {otolith }}$ ranges of -5.4 to $-2.3 \%$ for $F$. amboinensis and -3.7 to $-2.3 \%$ or $N$. taeniurus corresponded to 6 to 30 psu and 19 to $30 \mathrm{psu}$, respectively, when compared to the 2 extreme salinity values of the reference fishes. Terapon jarbua, in contrast, exhibited a $\delta^{18} \mathrm{O}_{\text {otolith }}$ range of -3.0 to $-1.8 \%$, corresponding to 25 to $34 \mathrm{psu}$. Field observations in other studies have indicated that F. amboinensis and N. taeniurus may be resident species, hovering near mangrove roots and tolerating a variable salinity environment, whereas T. jarbua may be a vagile species that can move to areas of preferred higher salinity conditions. Such behavioral ecologies are largely consistent with the salinity histories reconstructed from $\delta^{18} \mathrm{O}_{\text {otolith }}$ data. These results suggest that $F$. amboinensis and $N$. taeniurus may be estuarine resident fishes, whereas $T$. jarbua may be a marine migrant.
\end{abstract}

KEY WORDS: Fibramia amboinensis · Neopomacentrus taeniurus · Terapon jarbua · Estuary • Habitat $\cdot$ Space use $\cdot$ Stable isotope analysis

\section{INTRODUCTION}

Tropical and subtropical estuaries often support large numbers of fish species and individuals, and provide nursery habitats for juvenile fishes (Robertson \& Duke 1987, Meynecke et al. 2007, Nagel-

\footnotetext{
*Corresponding author: kshirai@aori.u-tokyo.ac.jp
}

kerken et al. 2008). Therefore, such estuaries are believed to be essential for high biodiversity in coastal ecosystems and local fisheries (Blaber 2000, Manson et al. 2005). In recent decades, however, tropical estuaries have been lost or degraded by human activities, including aquaculture, timber pro- 
duction and coastal urbanization (Duke et al. 2007). Such alternations of habitats affect estuarine fishes, decreasing fish species richness and abundance (Shinnaka et al. 2007, Mwandya et al. 2009), and thus conservation and management of tropical estuaries and estuarine fishes must be undertaken.

Recent degradation and loss of tropical estuaries due to human impact have made necessary the identification, prioritization and protection of essential habitats for estuarine fishes. Because fishes occurring in estuaries have different estuarine use patterns throughout their life histories (Elliott et al. 2007), understanding of such patterns may contribute greatly in identifying essential habitat conditions. Estuarine fishes typically include marine migrant species that spawn at sea and enter estuaries as juveniles (often in large numbers), and estuarine resident species that complete their entire life cycle within the estuarine environment, except the larval phases of some species (Elliott et al. 2007). For example, some lutjanid fishes, such as Lutjanus fulvus and L. fulviflamma, use estuaries as juveniles and move to marine habitats with growth (marine migrants) (Nakamura et al. 2008, Kimirei et al. 2013), whereas the hemiramphid Zenarchopterus dunckeri spends its entire life cycle within an estuary (estuarine resident species) (Kanai et al. 2014). To maintain fish populations, estuaries with unrestricted connections to marine areas are useful for most marine migrant species, but not for estuarine resident species, due to little or no larval input from marine areas and other estuaries. The latter species may be affected directly by estuarine habitat degradation throughout almost all life history stages, resulting in an increased risk of localized extinction. Accordingly, an estuary dominated by estuarine resident fishes may necessitate conservation and management on a small spatial scale (i.e. at each estuary or island). In contrast, for marine migrants, maintaining connectivity between marine and estuarine areas as well as avoiding crucial events which seriously decrease larval supply during their recruitment season may be important (Sheaves 2016), requiring a broader spatial scale. For effective conservation and management of estuarine fishes, therefore, a better understanding of their estuarine use patterns and migration ecology between estuaries and marine areas is essential. However, the migration ecology of most tropical estuarine fish species has not been well documented, partly because of the technical difficulties of studying individual fish movements (Kimirei et al. 2013).

Reconstruction of migratory ecology using fish otoliths, which can compensate for such drawbacks, is a useful technique for understanding the habitatuse ecology of fishes. Although the $\mathrm{Sr} / \mathrm{Ca}$ ratio of otoliths has been widely used to reconstruct fish migration (e.g. Tsukamoto et al. 1998, Zimmerman 2005, Amano et al. 2013), application to brackish water environments is sometimes problematic due to the small changes in salinity above 10 psu (Surge \& Lohmann 2002, Zimmerman 2005, Brown \& Severin 2009) and biological modification (Elsdon et al. 2008, Sturrock et al. 2012, Amano et al. 2015). In contrast, oxygen isotopic composition of fish otoliths (hereafter $\delta^{18} \mathrm{O}_{\text {otolith }}$ ) is essentially determined by the combination of temperature and the oxygen isotopic composition of ambient water (hereafter $\delta^{18} \mathrm{O}_{\text {water }}$ ) (Radtke et al. 1996, Thorrold et al. 1997, Sakamoto et al. 2017), the latter in an estuary showing a large and marked geographic gradient associated with salinity, the socalled 'isoscape' (e.g. Bowen 2010). Oxygen stable isotopic ratios of seawater are generally about $0 \%$ (Standard Mean Ocean Water [SMOW] scale) in salinities above 30 psu (LeGrande \& Schmidt 2006), whereas those of freshwater (salinity $=0 \mathrm{psu}$ ) reach from -20 to $-2 \%$ (LeGrande \& Schmidt 2006, Bowen $2008)$; thus the contribution of salinity change to $\delta^{18} \mathrm{O}_{\text {otolith }}$ is expected to be greater than that caused by temperature change (e.g. Amano et al. 2015). However, there have been only a few cases where $\delta^{18} \mathrm{O}_{\text {otolith }}$ has been used to determine individual salinity history associated with migration (e.g. Elsdon \& Gillanders 2002, Kerr et al. 2007, Tanner et al. 2013).

The aim of the present study was to quantitatively examine the salinity histories experienced by individuals representing 3 mangrove-inhabiting fish species and relate the findings back to the suspected ecology and life histories of the species. $\delta^{18} \mathrm{O}_{\text {otolith }}$ values for reef (i.e. fully marine) and freshwater fishes were analyzed so as to establish extreme salinity (end-member) values for use as reference points for improved reliability in salinity estimation. Possible causes of error in quantitative estimation, and limitations and further improvements to the protocol for salinity reconstruction using $\delta^{18} \mathrm{O}_{\text {otolith, }}$ are discussed.

\section{MATERIALS AND METHODS}

\section{Study species}

To determine the oxygen isotopic ratio of otoliths $\left(\delta^{18} \mathrm{O}_{\text {otolith }}\right)$ as end-members of salinity, namely in freshwater and marine environments, the kuhliid Kuhlia rupestris and the pomacentrid Chrysiptera 
cyanea were employed as appropriate representatives. Kuhlia rupestris is believed to be catadromous, usually occurring in freshwater, but migrating from freshwater to the ocean to reproduce (Lewis \& Hogan 1987). Chrysiptera cyanea is a typical reef-associated damselfish, widely inhabiting coral reefs, but never observed in estuarine areas (Shibuno et al. 2008). We considered that $\delta^{18} \mathrm{O}_{\text {otolith }}$ values from such individuals reflected upper (C. cyanea, seawater) and lower ( $K$. rupestris, only the otolith portion formed when this species inhabited freshwater) salinity levels, and used these to interpret $\delta^{18} \mathrm{O}_{\text {otolith }}$ of estuarine mangrove fishes. A calibration equation from $\delta^{18} \mathrm{O}_{\text {otolith }}$ values to salinity was established based on the relative difference of $\delta^{18} \mathrm{O}_{\text {otolith }}$ and habitat salinity between $C$. cyanea and $K$. rupestris.

To quantitatively reconstruct the salinity history of estuarine mangrove fishes, we used the apogonid Fibramia amboinensis, the pomacentrid Neopomacentrus taeniurus and the terapontid Terapon jarbua, the 3 species often being dominant in tropical East Asian estuaries (Nanjo et al. 2014a,b). The former 2 species, small fishes usually associated with mangrove roots (Nanjo et al. 2014a,b), are believed to spend most of their lives within estuaries, whereas the latter is a mobile marine migrant, occurring in estuaries as juveniles. Such estuarine use patterns throughout their life cycles are evidenced only by snapshot observations of their distribution and behavior (Whitfield 1990, Nanjo et al. 2014a, Inoue et al. 2016b); the generality of such patterns requires confirmation by more reliable methods, such as otolith geochemistry.

\section{Study site and samples}

The study was conducted in the Urauchi River $\left(24^{\circ} 24^{\prime} \mathrm{N}, 123^{\circ} 46^{\prime} \mathrm{E}\right)$, situated on the northern side of Iriomote Island, Ryukyu Islands, Japan (Fig. 1). With a drainage area of $54 \mathrm{~km}^{2}$, the river is $39 \mathrm{~km}$ in length, feeding into Urauchi Bay. The brackish water zone ranges $8 \mathrm{~km}$ upstream from the river mouth, with mangrove forests dominated by the red mangrove Rhizophora stylosa. The tidal range within the river is approximately $1.5 \mathrm{~m}$, and the prop roots are inundated at high tide and partially exposed at low tide. Detailed environmental descriptions of the study area have been reported elsewhere (Kanai et al. 2014, Nanjo et al. 2014a,b). Summer seawater temperatures typically reach ca. $29^{\circ} \mathrm{C}$ (July), the lowest winter water temperatures being ca. $21^{\circ} \mathrm{C}$ (January or February), as observed at Ishigaki Island, about $50 \mathrm{~km}$ distant on a similar latitude (Shirai et al.
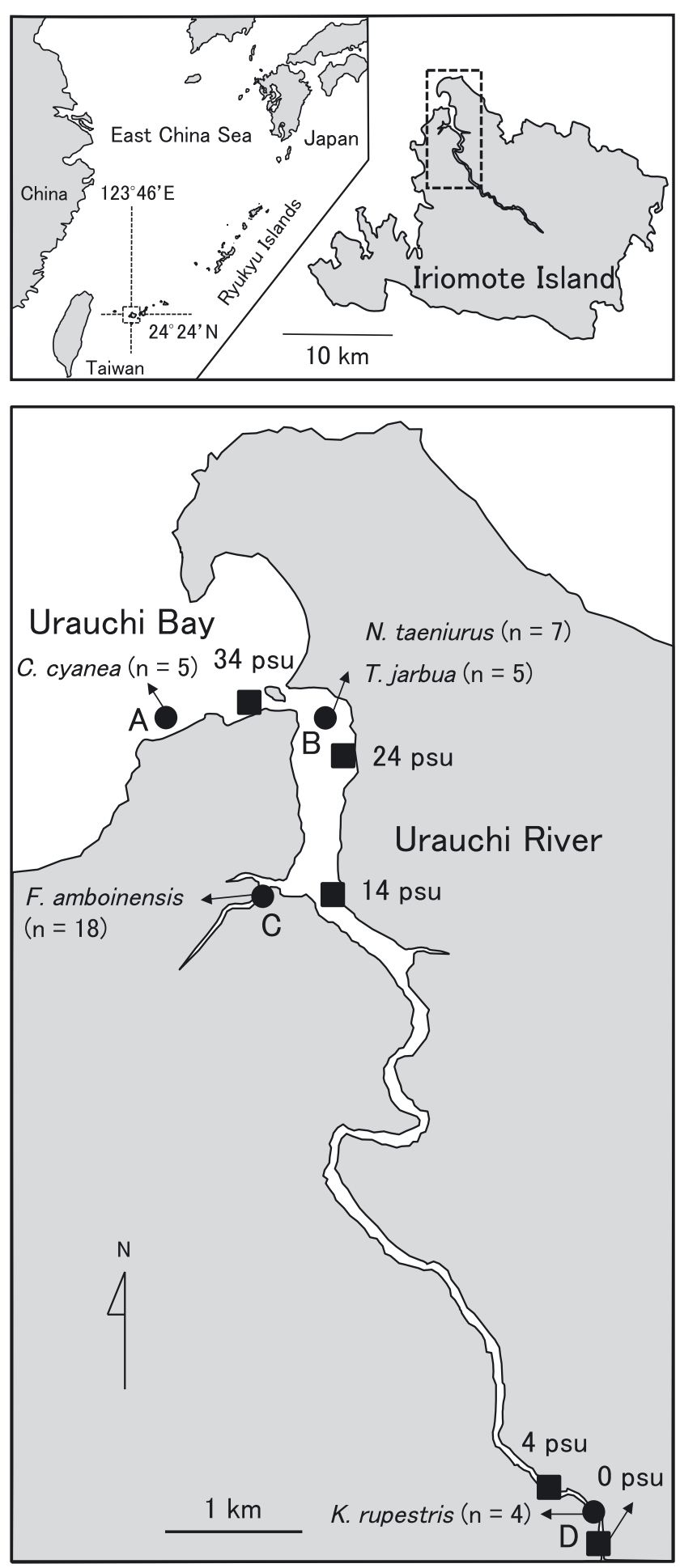

Fig. 1. Urauchi River estuary, Iriomote Island, Ryukyu Islands, Japan. Closed circles (A-D) indicate fish sampling stations (downstream and upstream) and closed squares water sampling locations; numbers represent salinity (psu). Chrysiptera cyanea and Kuhlia rupestris were reference species for fully marine and freshwater habitats, respectively; Neopomacentrus taeniurus, Terapon jarbua and Fibramia amboinensis were the study species 
2008), where the climate pattern of temperature and rainfall are nearly identical (Ushie et al. 2010). River temperature in summer and winter is $29-31^{\circ} \mathrm{C}$ (June-August) and ca. $20^{\circ} \mathrm{C}$ (January), respectively, the amplitude of annual variation being generally greater than that of seawater (Kosuge \& Kohno 2010). River temperature also varies over a scale of several hundred meters. For example, Ushie et al. (2010), who measured Urauchi River temperatures, reported $3^{\circ} \mathrm{C}$ higher temperature in a small runoff stream than in the trunk stream during 6-9 March 2007. Kanai et al. (2014) also reported temperature variation across a salinity gradient in the river in June 2013, being $24.5,26.7,28.7$ and $27.3^{\circ} \mathrm{C}$ in water with salinites of $7.0,15.1,25.1$ and $32.2 \mathrm{psu}$, respectively.

In total, 39 fishes were sampled at 4 points (A-D) in the study area during ebb tide using small seine and dip nets (Fig. 1). Ambient water salinity was measured at the same time by a Hydrolab Model Quanta Multi-Probe Meter. In August 2015, the estuarine fishes $N$. taeniurus $(\mathrm{n}=7)$ and $T$. jarbua $(\mathrm{n}=5)$ were sampled from point B (24 psu), whereas F. amboinensis $(\mathrm{n}=18)$ was caught at point $\mathrm{C}(20 \mathrm{psu})$, the estuarine sampling points being 0.3 and $2 \mathrm{~km}$ from the river mouth, respectively. In September 2015, the marine fish $C$. cyanea $(\mathrm{n}=5)$ was collected from sampling point A (34 psu), in the reef flats in Urauchi Bay, and $K$. rupestris $(\mathrm{n}=4)$ was collected from point D $(0 \mathrm{psu})$, in the upper freshwater area of the river. The standard length (SL) of each fish was measured and used for growth stage determination, based on the relationship between SL and gonad maturity (K. Nanjo et al. unpubl. data). Fibramia amboinensis individuals $>49 \mathrm{~mm}$ SL were determined to be adults, whereas all T. jarbua individuals collected were juveniles. Although we had no data regarding mature sizes for $N$. taeniurus, the collected individuals likely included both juveniles and adults, judging from the maximum size of this species (85 mm SL) (Allen 1991). Whole specimens were frozen for subsequent otolith analysis (see Table S1 in the Supplement at www.int-res.com/articles/suppl/m593p127_supp.xlsx).

Two bottles of ambient water samples for oxygen isotope analysis were taken at 5 points, at salinities of 34, 24, 14, 4 and 0 psu (Fig. 1), from the marine bay to the mid region of the river during ebb tide on 27 and 28 August 2015, and kept in clean 20-ml glass vials.

\section{Sample preparation and analysis}

Sagittal otoliths were dissected out and adherent tissue was removed with tap water, before being dried and stored in a microtube. Otoliths were embedded in epoxy resin (Araldite Rapid R30) on a glass slide, ground with a graded series of alumina paste and subjected to final polishing with colloidal silica suspension. The polished section was cleaned with Milli-Q water for $10 \mathrm{~min}$ in an ultrasonic bath and dried.

Otolith growth increments were extracted using a high-precision micromilling system (GEOMILL326, Izumo-web). This comprised a micromill, digital microscope, video monitor and computer-controlled image analyzer, and enabled accurate positioning on a 1/1000 mm scale and drilling along a growth line with <10 $\mu \mathrm{m}$ precision (Sakai 2009). Otoliths were micromilled from the otolith margin to the core at intervals of approximately 100-300 $\mu \mathrm{m}$ (200 $\mu \mathrm{m}$ on average), to a depth of 100-300 $\mu \mathrm{m}(110 \mu \mathrm{m}$ on average), depending on otolith size and shape, resulting in a powder of 30-500 $\mu \mathrm{g}$ (140 $\mu \mathrm{g}$ on average). In most cases, the core portion was broken when micromilling occurred too close to the core, possibly due to decreasing mechanical strength; accordingly, much core portion data could not be obtained. After each micromilling procedure, the otolith section was photographed using a digital microscope (VHX-5000, KEYENCE) to confirm the micromilling path. The width of the path was then measured using image analysis software (ImageJ, available at http://imagej. nih.gov/ij/). Photographs were taken under reflected or transmitted light, whichever provided better visibility of growth patterns. After milling, the otolith powder was collected onto a piece of aluminum foil and transferred to a glass vial for isotope analysis.

The stable oxygen isotope ratio of each otolith $\left(\delta^{18} \mathrm{O}_{\text {otolith }}\right)$ powder sample was measured using an isotope ratio mass spectrometer (Delta V plus, Thermo Fisher Scientific), equipped with an automated carbonate reaction device (GasBench II, Thermo Fisher Scientific), installed at the Atmosphere and Ocean Research Institute, University of Tokyo, Tokyo. Otolith powder was introduced into a glass vial, flushed with pure helium and reacted with $100 \%$ phosphoric acid at $72^{\circ} \mathrm{C}$. Liberated $\mathrm{CO}_{2}$ was transported with the helium gas flow to the mass spectrometer. Detailed analytical conditions have been reported elsewhere (e.g. Kubota et al. 2017). All isotope values are reported using delta notation with respect to Pee Dee Belemnite (PDB), based on an NBS-19 value of $-2.20 \%$ for $\delta^{18} \mathrm{O}_{\text {otolith. No correction was applied for }}$ the acid fractionation factor between calcite and aragonite (phosphoric acid-calcium carbonate reaction temperature $72^{\circ} \mathrm{C}$; Kim et al. 2007b). Repeated analysis of the NBS-19 standard yielded an external 
reproducibility of $\delta^{18} \mathrm{O}_{\text {otolith }}$ measurements better than $0.14 \%$ (1 SD).

Oxygen isotope compositions of the water $\left(\delta^{18} \mathrm{O}_{\text {water }}\right)$ samples were determined using the Picarro L2120-i Analyzer at the Atmosphere and Ocean Research Institute, University of Tokyo. Before introduction into the analyzer, samples were filtered using a membrane filter (pore size: $0.45 \mu \mathrm{m}$, Toyo Roshi Kaisha) to reduce suspended particles and prevent blocking of the sampling line. Both bottles from each sampling point were analyzed and averaged values are presented, the deviations being smaller than long-term reproducibility. Data are reported in delta notation against the VSMOW (Vienna Standard Mean Ocean Water) reference standard. Long-term instrument reproducibility was $\pm 0.08 \%$.

\section{RESULTS}

\section{Relationship between $\delta^{18} \mathbf{O}_{\text {water }}$ and salinity}

Oxygen isotopic ratios of water $\left(\delta^{18} \mathrm{O}_{\text {water }}\right)$ were $0.28,-1.45,-3.93,-5.12$ and $-5.07 \%$ osmow at salinities of $34,24,14,4$ and 0 psu, respectively. The linear relationship between ambient water salinity and $\delta^{18} \mathrm{O}_{\text {water }}\left(\mathrm{r}^{2}=0.96\right.$; Fig. 2) was as follows:

$$
\delta^{18} \mathrm{O}_{\text {water }}(\% \text { smow })=(0.17 \times \text { salinity })+5.64
$$

\section{Otolith oxygen isotope pattern}

The results of otolith oxygen isotope $\left(\delta^{18} \mathrm{O}_{\text {otolith }}\right)$ determinations for individual specimens are shown in Table S1 and Fig. 3, and characteristics of species $\delta^{18} \mathrm{O}_{\text {otolith }}$ values are summarized in Table 1 . Species means were calculated from all increment data from all individuals. Species maxima and minima were

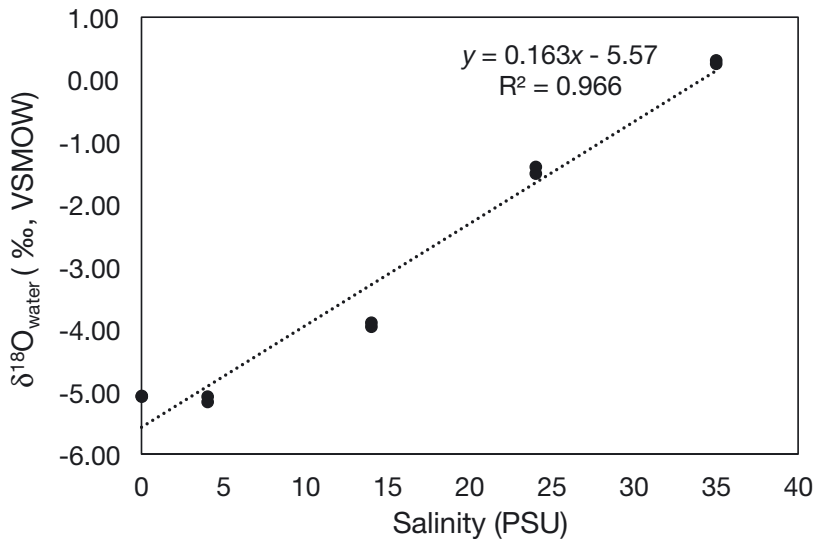

Fig. 2. Relationship between salinity and $\delta^{18} \mathrm{O}_{\text {water }}$. The linear regression equation and $\mathrm{R}^{2}$ value also shown. VSMOW: Vienna Standard Mean Ocean Water

chosen from all data from all individuals. Maximum and minimum specimen averages were obtained by averaging all data from an individual, and were taken from the highest and lowest values, respectively. Average variability within specimens represents the averaged value of fluctuation ranges within each individual. In Fig. 3, line colors are graded in descending order of edge portion (the time of otolith composition closest to the sampling date) value. $\delta^{18} \mathrm{O}_{\text {otolith }}$ in the catadromous fish Kuhlia rupestris showed relatively higher values $(>-5.7 \%$ ордв) in the inner portion compared with the outer portion in 3 out of 4 individuals. At the outer portion (>1500$2000 \mu \mathrm{m}), \delta^{18} \mathrm{O}_{\text {otolith }}$ ranged from -6.7 to $-5.7 \%$ opDB but did not show any clear trends (Fig. 3a). We regarded the situation in which $\delta^{18} \mathrm{O}_{\text {otolith }}$ decreased from the core toward the margin to a value lower than the highest recorded for the remaining section as the completion of entry into freshwater, and treated the remaining portion as representing freshwater habitat periods (hereafter freshwater periods).

Table 1. Characteristics of species $\delta^{18} \mathrm{O}_{\text {otolith }}$ values (\%)

\begin{tabular}{|c|c|c|c|c|c|c|c|c|c|c|}
\hline \multirow{2}{*}{$\begin{array}{l}\text { Fish species } \\
\text { (salinity at the sampling site) }\end{array}$} & \multicolumn{3}{|c|}{${ }_{-}$Species -} & \multicolumn{3}{|c|}{ Within-specimen average } & \multicolumn{3}{|c|}{$\ldots$ Edge -} & \multirow{2}{*}{$\begin{array}{c}\text { No. of } \\
\text { specimens }\end{array}$} \\
\hline & Mean & Max. & Min. & Max. & Min. & Variability & Mean & Max. & Min. & \\
\hline Kuhlia rupestris (freshwater, 0 psu) & $\begin{array}{l}-6.0 \\
(-6.3)^{\mathrm{b}}\end{array}$ & $\begin{array}{l}-3.7 \\
(-5.5)^{b}\end{array}$ & $\begin{array}{l}-6.7 \\
(-6.7)^{b}\end{array}$ & & & & -6.0 & -5.5 & -6.5 & 4 \\
\hline Chrysiptera cyanea (marine, 34 psu) & -1.7 & -1.4 & -2.1 & & & & -1.7 & -1.4 & -2.0 & 5 \\
\hline Fibramia amboinensis (20 psu) & -3.4 & $\begin{array}{l}-1.8 \\
(-2.3)^{\mathrm{a}}\end{array}$ & -5.4 & -2.7 & -4.9 & 1.1 & -3.0 & $\begin{array}{l}-1.8 \\
(-2.3)^{\mathrm{a}}\end{array}$ & -4.9 & 18 \\
\hline Neopomacentrus taeniurus (24 psu) & -2.9 & -2.3 & -3.7 & -2.5 & -3.0 & 0.6 & -2.8 & -2.4 & -3.7 & 7 \\
\hline Terapon jarbua (24 psu) & -2.4 & -1.8 & -3.0 & -2.1 & -2.8 & 0.5 & -2.4 & -2.1 & -2.7 & 5 \\
\hline
\end{tabular}




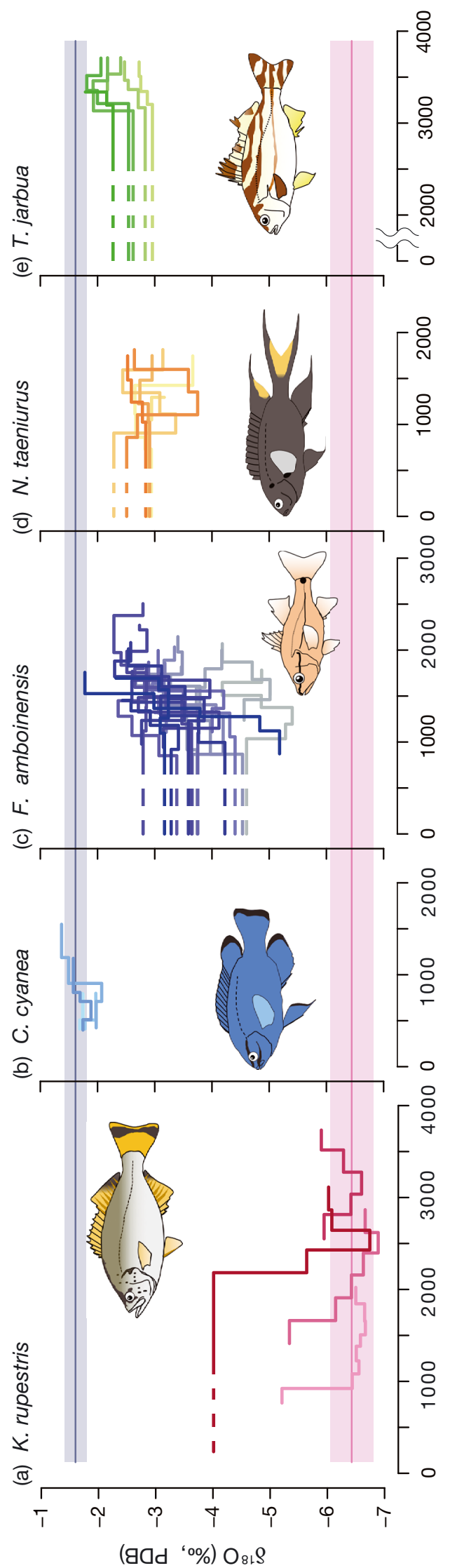

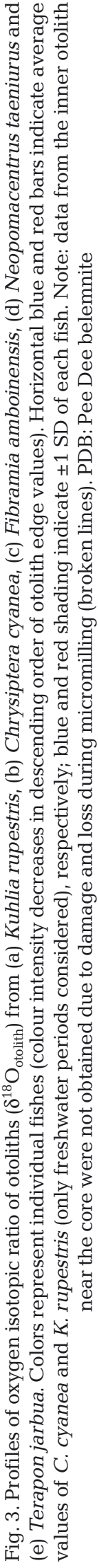

The difference in $\delta^{18} \mathrm{O}_{\text {otolith }}$ between freshwater $(K$. rupestris) and marine (Chrysiptera cyanea) species was $4.5 \%$, a value close to $5.4 \%$ (being the difference between the $\delta^{18} \mathrm{O}_{\text {water }}$ of seawater and freshwater). One specimen of Fibramia amboinensis (no. 74) exhibited an anomalously high value. Exclusion of this individual reduced the range of fluctuation and the maximum value significantly, such values after exclusion being used for further discussion of this species.

Specimen means were in the order Terapon jarbua (highest), Neopomacentrus taeniurus and F. amboinensis, with the range of averaged $\delta^{18} \mathrm{O}_{\text {otolith }}$ values (i.e. difference between maximum and minimum value) from each individual in the order $F$. amboinensis (highest), T. jarbua and $N$. taeniurus, and average variability within specimens in the order $F$. amboinensis (highest), N. taeniurus and T. jarbua. At the edge portion, $F$. amboinensis specimens with higher edge $\delta^{18} \mathrm{O}_{\text {otolith }}$ composition tended to exhibit a higher $\delta^{18} \mathrm{O}_{\text {otolith }}$ composition in the previous portion, as shown in Fig. 3c. However, this relationship was unclear for $N$. taeniurus and $T$. jarbua, possibly due to the limited number of specimens examined.

The $\delta^{18} \mathrm{O}_{\text {water }}$ of reef seawater was $0.3 \%$ osmow, and that of 0 and 4 psu freshwater was $-5.1 \%$ osmow. Seawater and freshwater salinity differed by $34 \mathrm{psu}$, and $5.4 \%{ }_{\text {SMOw }}$ in $\delta^{18} \mathrm{O}_{\text {water }}$.

Regarding the averaged $\delta^{18} \mathrm{O}_{\text {otolith }}$ value of all data from all individuals of C. cyanea $(-1.7 \%)$ as the endmember of $\delta^{18} \mathrm{O}_{\text {otolith }}$ by marine deposition in $34 \mathrm{psu}$, and that of $K$. rupestris $(-6.3 \%$ ) from freshwater periods as the freshwater $\delta^{18} \mathrm{O}_{\text {otolith }}$ end-member in $0 \mathrm{psu}$, the relationship between salinity and $\delta^{18} \mathrm{O}_{\text {otolith }}$ can be expressed as follows:

$$
\text { Salinity }(\mathrm{psu})=7.6 \times \delta^{18} \mathrm{O}_{\text {otolith }}(\% \text { орDB })+47.2
$$

The $\delta^{18} \mathrm{O}_{\text {otolith }}$ ranges for $F$. amboinensis $(-5.4$ to $-2.3 \%$, excluding one anomalous individual), $N$. taeniurus $(-3.7$ to $-2.3 \%)$ and $T$. jarbua $(-3.0$ to $-1.8 \%$ ) corresponded to experienced salinity of 6 to $30 \mathrm{psu}, 19$ to $30 \mathrm{psu}$ and 25 to $34 \mathrm{psu}$, respectively, following conversion to salinity using Eq. (2).

\section{DISCUSSION}

\section{Usefulness of otolith oxygen isotopic ratios as proxies of experienced salinity}

The agreement of the differences in $\delta^{18} \mathrm{O}$ values from otoliths of the catadromous Kuhlia rupestris (only freshwater periods considered) and the fully marine Chrysiptera cyanea with those of $\delta^{18} \mathrm{O}_{\text {water }}$ 
from reef water and freshwater indicates that $\delta^{18} \mathrm{O}_{\text {otolith }}$ values can be used as reliable proxies for the ambient salinities experienced by fishes. $\delta^{18} \mathrm{O}_{\text {otolith }}$ is considered to be formed near or at isotopic equilibrium (Patterson et al. 1993, Radtke et al. 1996, Thorrold et al. 1997, Høie et al. 2004, Kitagawa et al. 2013, Sakamoto et al. 2017). Although several studies have pointed out the possibility of species-specific isotopic fractionation (e.g. Høie et al. 2004, Storm-Suke et al. 2007, Godiksen et al. 2010), even in the extreme case of the temperature- $\delta^{18} \mathrm{O}_{\text {otolith }}$ conversion equation of Godiksen et al. (2010) being taken as the highest output and that of Radtke et al. (1996) or Thorrold et al. (1997) as the lowest output of $\delta^{18} \mathrm{O}_{\text {otolith }}$ calculated from a given temperature (e.g. $25^{\circ} \mathrm{C}$ ), species dependency is less than $\sim 2 \%$ (corresponding to $\sim 8^{\circ} \mathrm{C}$ ). It should be noted that this estimation is a maximum range of species-specific fractionation, but also includes some effects of analytical method discrepancies, such as difference in reaction temperature and presence/absence of correction for the acid fractionation factor (Amano et al. 2015). In most cases, a species-specific variation of $\sim 1 \%$ o (see Fig. 3 in Sakamoto et al. 2017) can be taken as an adequate estimate. The lack of a dietary effect on $\delta^{18} \mathrm{O}_{\text {otolith }}$ (Radtke et al. 1996) also supports a small speciesspecific effect. Such evidence of the relatively small biological control of $\delta^{18} \mathrm{O}_{\text {otolith }}$ reliably reflects the combined effects of temperature and the ambient water oxygen isotopic ratio. In addition, the fluctuation pattern of $\delta^{18} \mathrm{O}_{\text {otolith }}$ associated with the growth of $K$. rupestris supports the reliability of $\delta^{18} \mathrm{O}_{\text {otolith }}$ as an indicator of habitat salinity. Kuhlia rupestris lives in seawater during the juvenile stage, shifting its habitat to freshwater as it grows (Feutry et al. 2012). In 3 of 4 individuals, $\delta^{18} \mathrm{O}_{\text {otolith }}$ was high for the inner portion (corresponding to younger ontogeny), with $\delta^{18} \mathrm{O}_{\text {otolith }}$ tending to decrease with growth. This was consistent with the ontogenetic migratory ecology of K. rupestris.

The difference in $\delta^{18} \mathrm{O}_{\text {otolith }}$ among species seems to mainly represent differences in experienced salinity, even though river and seawater temperatures vary widely over the annual cycle and at a small spatial scale. The seasonal fluctuations in seawater and river water temperature around the study area of $8^{\circ} \mathrm{C}$ (Shirai et al. 2008) and $11^{\circ} \mathrm{C}$ correspond to $2 \%$ and $\sim 3 \%$, respectively, in terms of oxygen isotopic fractionation under isotope equilibrium (Kim et al. 2007a). In contrast, the $\delta^{18} \mathrm{O}_{\text {water }}$ of reef water was $5.4 \%$ higher than that of freshwater, and the $\delta^{18} \mathrm{O}_{\text {otolith }}$ of catadromous $K$. rupestris during freshwater periods was $4.5 \%$ higher than that of the fully marine fish C. cyanea.
This indicates that the influence of salinity change (change in $\delta^{18} \mathrm{O}_{\text {water }}$ ) is greater than that of temperature change. The lower resolution of $\delta^{18} \mathrm{O}_{\text {otolith }}$ analysis also compensates for the effect of seasonal temperatures approaching average values. In fact, the fluctuation range of $\delta^{18} \mathrm{O}_{\text {otolith }}$ of $C$. cyanea and $K$. rupestris (only freshwater periods considered) was $0.7 \%$ and $1.1 \%$, respectively. These were less than the $2 \%$ and $\sim 3 \%$ values, respectively, estimated from seasonal seawater and river water temperature changes. Additionally, the mean $\delta^{18} \mathrm{O}_{\text {otolith values of }}$ C. cyanea and $K$. rupestris corresponded to 27.1 and $23.1^{\circ} \mathrm{C}$, respectively, when temperature was calculated using the temperature- $\delta^{18} \mathrm{O}_{\text {otolith }}$ equation of Kim et al. (2007a) and $\delta^{18} \mathrm{O}_{\text {water }}$ values of each endmember. These temperatures were within the range of seasonal temperature fluctuation, supporting the validity of observed $\delta^{18} \mathrm{O}_{\text {otolith values as representa- }}$ tives of annual mean temperature. The degree of discrepancy was $4{ }^{\circ} \mathrm{C}$, corresponding to $1 \%$. This difference may induce an accuracy error of $22 \%$ for absolute salinity estimation based on Eq. (2).

Seasonal fluctuations in $\delta^{18} \mathrm{O}_{\text {water }}$ of freshwater as well as heterogeneous river water temperature in the water system may also influence $\delta^{18} \mathrm{O}_{\text {otolith }}$, but such an effect is considered to be less than $1.1 \%$ o (the fluctuation range in $K$. rupestris during freshwater periods). However, a temperature gradient occurs across the salinity gradient and from upper to lower stream levels (e.g. Ushie et al. 2010, Kanai et al. 2014). Furthermore, in tropical and sub-tropical areas, hypersalinity conditions caused by active evaporation sometimes induces isotopic fractionation, which is independent of seawater-freshwater mixing (e.g. Gillanders \& Munro 2012, Walther \& Nims 2015). These environmental settings may induce systematic errors in salinity estimation; thus caution is required, especially when analytical resolution is much higher than that of seasonal otolith growth. On the contrary, the analytical resolution employed in the present study seemed to emphasize a representative habitat salinity by averaging seasonal temperature fluctuations. Therefore, the abovementioned possible causes of salinity estimation error are quantitatively small enough to allow the comparison of habitat salinity differences among species in the mangrove estuary.

\section{Habitat-use ecology of mangrove fishes by salinity reconstruction}

The estimated experienced salinity for Fibramia amboinensis and Neopomacentrus taeniurus was 6 to 
$30 \mathrm{psu}$ and 19 to $30 \mathrm{psu}$, respectively. Despite all individuals having been collected from the same sampling points for each species, they demonstrated a wide range of salinity. However, averaged values from the otolith edge ( $-3.0 \%$ for both species) corresponded to $24 \mathrm{psu}$, close to the ambient salinity at the time of fish sampling, indicating that fishes with a wide range of experienced salinity history were gathered together locally, both species rarely inhabiting purely freshwater or seawater.

Both $F$. amboinensis and $N$. taeniurus are resident fishes, hovering near mangrove roots, although often schooling during the day. Since salinity fluctuates greatly in estuaries, resident fishes are usually exposed to a broad range of salinities. This was confirmed by the $\delta^{18} \mathrm{O}_{\text {otolith }}$ variations among individuals collected at the same station. The wider range of averaged $\delta^{18} \mathrm{O}_{\text {otolith }}$ values from each individual, and the higher averaged value of fluctuation ranges within each individual, indicated that $F$. amboinensis may tolerate lower salinity levels than $N$. taeniurus. In fact, the former occurred from lower to upper estuarine areas in the mangrove creek, whereas the latter was observed in lower and middle estuaries, but never in upper estuaries (Nanjo et al. 2014a). Such occurrence patterns of both fish species along a salinity gradient have been noted in other estuaries (Inoue et al. 2016b). Inoue et al. (2016a) examined tidal fluctuations in salinity and fish distribution in other tropical estuaries in the same region as the present study, and reported that $F$. amboinensis remained inactive, not changing their positions between high and low tides, whereas $N$. taeniurus avoided surface freshwater at ebb tides, moving closer to the substrata where high salinity water remained. These observations suggest that the 2 species may spend their entire post-settlement lives within an estuary. Such a behavioral ecology is largely consistent with their reconstructed salinity history from $\delta^{18} \mathrm{O}_{\text {otolith }}$ data. $\delta^{18} \mathrm{O}_{\text {otolith }}$ data also provide further insights into the migration behavior of $F$. amboinensis at a small spatial scale. The experienced salinity of $F$. amboinensis collected from point $C$ (20 psu) ranged down to 6 psu, whereas the salinity at that point rarely decreased to below $10 \mathrm{psu}$, except for a limited duration during low tides, suggesting that individuals with lower experienced salinity may have migrated from the upper part of the creek. Unfortunately, such analysis could not be applied to $N$. taeniurus and Terapon jarbua because of the small sample sizes.

Additionally, most apogonids are known to incubate their eggs orally (Nelson 2006), newly hatched apogonid larvae being relatively large (ca. $6 \mathrm{~mm}$ in total length) (Neira 1991). Indeed, adult F. amboinensis with eggs in their mouths have been observed in spring in the Urauchi River estuary ( $\mathrm{K}$. Nanjo pers. obs.). In contrast, although little is known about the reproduction of $N$. taeniurus, the congeneric $N$. cyanomos spawns adhesive eggs that attach to hard substrata, a large male protecting them until hatching (the larvae are also relatively large, ca. 3 mm; Loh et al. 2013). Larvae with a large body size usually have some swimming ability and in some species, they have the potential to actively modify their dispersal patterns (Fisher et al. 2000). In addition, fish larvae hatched from demersal eggs are more developed in terms of swimming ability than larvae from pelagic eggs (Kobayashi 1989), and are more likely to be able to remain near the natal habitat (Brogan 1994). Accordingly, the large larvae of $F$. amboinensis and $N$. taeniurus, which may have some swimming ability that prevents them from being washed out to sea by ebb tide currents, may hatch and remain within the estuary. Based on these observations and $\delta^{18} \mathrm{O}_{\text {otolith }}$ data, we suggest that $F$. amboinensis and $N$. taeniurus may be estuarine resident fishes, spending their entire larval phase to adult life within an estuary. However, supporting data for their reproduction and dispersal (i.e. ratio of individuals accidentally transported out of the estuary) during their larval phases are still insufficient because we were unable to analyze the inner otolith portion in either species.

In $T$. jarbua, in contrast, reconstructed experienced salinity corresponded to 25 to $34 \mathrm{psu}$. The salinity levels experienced were relatively narrower and higher than in the 2 estuarine residents, suggesting that $T$. jarbua prefers a relatively high salinity environment. Being a vagile species, able to move to estuarine areas of more suitable salinity, $T$. jarbua has been observed to enter the study mangrove creek at high tide (Nanjo et al. 2014a), moving to lower areas (near river mouth) with high salinity water at low tide. Such movements, reflecting tidal cycles, may be responsible for their narrow salinity history as reconstructed from the $\delta^{18} \mathrm{O}_{\text {otolith }}$ analysis. Terapon jarbua is believed to be a marine migrant (Whitfield 1990), utilizing estuaries as juveniles, with the adults spawning in the sea. The present results indicated that juveniles of this vagile marine species may migrate briefly with high salinity water into estuaries. However, this needs to be confirmed by analysis of a greater sample size. 


\section{Advantages and limitations of the present study, and future perspectives}

The use of $\delta^{18} \mathrm{O}_{\text {otolith }}$ data for salinity reconstruction has both advantages and limitations compared with the use of trace elements. Because the concentrations of $\mathrm{Ca}$ and $\mathrm{Sr}$ in river water may be lower than those in seawater, the $\mathrm{Sr} / \mathrm{Ca}$ ratio of environmental water does not change greatly in brackish zones where salinity is above 10 psu (Surge \& Lohmann 2002, Zimmerman 2005, Brown \& Severin 2009). For example, Brown \& Severin (2009) simulated the relationship between salinity and the $\mathrm{Sr} / \mathrm{Ca}$ ratio of water. Their analysis indicated that even if the $\mathrm{Sr} / \mathrm{Ca}$ ratio of freshwater varied significantly (from 2.01 to 13.83 mmol $\mathrm{mol}^{-1}$ ), mixing with seawater suppressed changes in the water $\mathrm{Sr} / \mathrm{Ca}$ ratio, leading to lower variability (e.g. $7.3-10.3 \mathrm{mmol} \mathrm{mol}^{-1}$ for $10 \mathrm{psu}$, $8.2-9.2 \mathrm{mmol} \mathrm{mol}^{-1}$ for $20 \mathrm{psu}$ and $8.5-8.7 \mathrm{mmol}$ $\mathrm{mol}^{-1}$ for $30 \mathrm{psu}$; Brown \& Severin 2009). Therefore, the response of the $\mathrm{Sr} / \mathrm{Ca}$ ratio to salinity change decreased with respect to salinity increase. Furthermore, otolith $\mathrm{Sr} / \mathrm{Ca}$ ratios are susceptible to strong biological control and do not reflect the composition of environmental water quantitatively or accurately (Otake et al. 1997, Brown \& Severin 2009, Walther et al. 2010). Kanai et al. (2014) validated the usefulness of the otolith Sr/Ca ratio as a salinity proxy for Zenarchopterus dunckeri, based on culture experiments from the same study area, and while they could distinguish between low ( $7 \mathrm{psu})$, medium (15 and $25 \mathrm{psu}$ ) and high (32 psu) salinity, separation of middle range salinities (between 15 and 22 psu) was impossible. Therefore, otolith $\mathrm{Sr} / \mathrm{Ca}$ ratios are likely to prove difficult for reconstructing movements, particularly in water with salinities between 10 and 30 psu. As an alternative, Li/Ca (Kanai et al. 2014), $\mathrm{Ba} / \mathrm{Ca}$ (Elsdon \& Gillanders 2004, McCulloch et al. 2005, Macdonald \& Crook 2010, Walther et al. 2011) and $\mathrm{Sr} / \mathrm{Ba}$ ratios (Walther et al. 2011) have been proposed as proxies of experienced salinity, but validation experiments or evaluation of species dependency and ontogenetic effects are necessary for such use (Elsdon et al. 2008).

The primary emphasis of the present study is the use of $\delta^{18} \mathrm{O}_{\text {otolith }}$ for salinity reconstruction, as it is almost exclusively controlled by water temperature and $\delta^{18} \mathrm{O}_{\text {water }}$. Since biological fractionation is small, variations in water temperature and $\delta^{18} \mathrm{O}_{\text {water }}$ are the only factors potentially responsible for errors in salinity estimation. If otolith dating was possible by backcalculating the number of growth rings from the date of collection, it would be possible to specify the date on which the sampled otolith portion was formed and estimate the water temperature on that day. This would enable the influence of water temperature to be subtracted, leading to an improvement in the accuracy of salinity estimation. Unfortunately, the otoliths examined in the present study did not show clear growth patterns, making the identification of annual or daily growth lines difficult, as seen in Fig. 4 (photographs of representative otolith crosssections).

If the temporal resolution of micromilling and seasonal growth rate fluctuations did not change so much for each fish species, the fluctuation range of $\delta^{18} \mathrm{O}_{\text {otolith }}$ in C. cyanea $(0.7 \%$, corresponds to $5.3 \mathrm{psu})$ could be treated as an error in salinity estimation caused by the effect of seasonal seawater temperature fluctuations. However, the $\delta^{18} \mathrm{O}_{\text {otolith }}$ fluctuation range in $T$. jarbua $(1.1 \%$, corresponds to $8.5 \mathrm{psu})$ can be treated as an error resulting from the combination of seasonal fluctuations in both river water temperature and freshwater $\delta^{18} \mathrm{O}_{\text {water }}$. For example, according to a report on seasonal variations in $\delta^{18} \mathrm{O}_{\text {water }}$ of precipitation on Okinawa Island, located ca. $480 \mathrm{~km}$ northeast of the study area (Uemura et al. 2012), the $\delta^{18} \mathrm{O}_{\text {water }}$ of precipitation is about $-7 \%$ in summer when precipitation is high, compared with about $-3 \%$ in winter (low precipitation). Accordingly, the $\delta^{18} \mathrm{O}_{\text {water }}$ of rivers differs according to the relative amount of precipitation and groundwater input, as those sources vary over time (Kendall \& Doctor 2003). The insignificant difference in $\delta^{18} \mathrm{O}_{\text {water }}$ between 0 and 5 psu water may be attributed to the variability in the $\delta^{18} \mathrm{O}_{\text {water }}$ of precipitation. Because summer high water temperature lowers $\delta^{18} \mathrm{O}_{\text {otolith, }}$ it emphasizes seasonal variations in $\delta^{18} \mathrm{O}_{\text {otolith. }}$. However, the timing of seasonal peak temperature and precipitation do not match exactly (Uemura et al. 2012). Therefore, several factors exist that potentially induce fluctuations in $\delta^{18} \mathrm{O}_{\text {otolith, }}$ but they are difficult to monitor in the river environment. To understand the $\delta^{18} \mathrm{O}_{\text {otolith }}$ precipitated at the extremes of the isoscape, it is very useful to treat the otoliths of freshwater and seawater fishes as references, together with the target species. This makes possible the partial cancellation of possible factors that can affect $\delta^{18} \mathrm{O}_{\text {otolith }}$ (other than salinity). The use of otoliths as references enables an evaluation of the influence of seasonal fluctuations via snapshot sampling over a short time period. In the present study, the relationship between salinity and $\delta^{18} \mathrm{O}_{\text {water }}$ was clarified, but only as a single-time snapshot, based on water samples collected within $2 \mathrm{~d}$. In fact, the actual range of annual fluctuation of the environmental water is still unknown; this is partly 

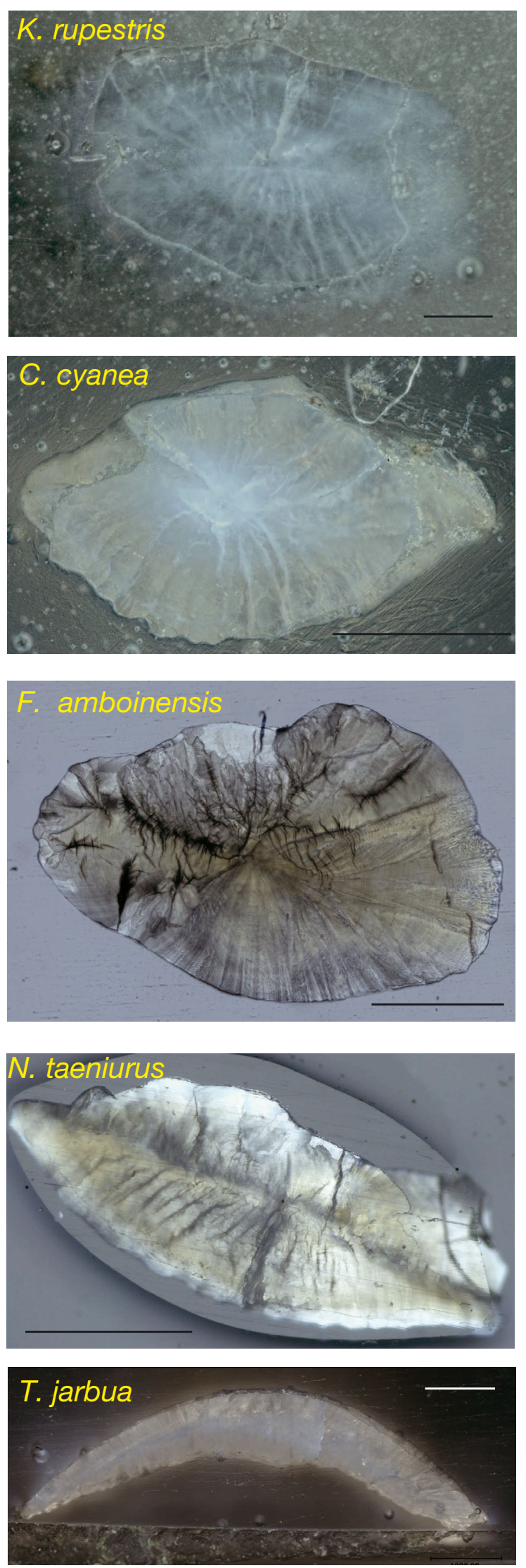

attributable to the small differences in freshwaterseawater $\delta^{18} \mathrm{O}_{\text {water }}$ and freshwater fish-seawater fish $\delta^{18} \mathrm{O}_{\text {otolith. }}$. In the present study, fish otoliths were used as end-members of the isoscape, but if possible, analysis along growth directions of aragonitic bivalve shells would be more informative, $\delta^{18} \mathrm{O}$ being produced under isotopic equilibrium, because it would provide time series and on-site information.

The salinity reconstruction using $\delta^{18} \mathrm{O}_{\text {otolith }}$ in the present study also had limitations. Since $\sim 100 \mu \mathrm{g}$ of powder was used in the present study, the micromilling resolution was often lower than $100 \mu \mathrm{m}$, which is higher than that of trace element analysis using electron probe micro-analysis and laser ablation inductively coupled plasma mass spectrometry. As a result, short-term movements could not be detected, with only the average experienced salinity being apparent. Furthermore, although the composition of the oxygen isotope ratio of body fluid being in equilibrium with that of environmental water was a primary requirement, the time taken to reach equilibrium (and driving mechanisms) has not yet been clarified. In addition, analysis of the otolith core portion of most individuals was problematic due to technical difficulties, although these should be overcome by greater technical experience and development. Both these issues are also applicable to trace element analysis, but may be resolved by special technology for oxygen isotopic analysis, such as secondary ion mass spectrometry (Shirai et al. 2010, in press) or trace carbonate analysis (Ishimura et al. 2004, 2008, Kitagawa et al. 2013, Sakamoto et al. 2017).

\section{CONCLUSION}

Reconstruction of the salinity history of 3 estuarine fishes (F. amboinensis, $N$. taeniurus and $T$. jarbua) using $\delta^{18} \mathrm{O}_{\text {otolith }}$ was presented. The $\delta^{18} \mathrm{O}_{\text {otolith }}$ ranges of $F$. amboinensis and $N$. taeniurus showed that they experienced a broad range of estuarine salinity levels compared with the relatively narrower and higher salinity history of $T$. jarbua. Field observations in previous studies have indicated that $F$. amboinensis and $N$. taeniurus may be resident fishes, hovering near mangrove roots and tolerating variable salinity environments, whereas $T$. jarbua may be a vagile species,

Fig. 4. Photographs of representative otolith cross-sections from Kuhlia rupestris, Chrysiptera cyanea, Fibramia amboinensis, Neopomacentrus taeniurus and Terapon jarbua. Scale bars $=1 \mathrm{~mm}$ 
moving to areas of preferred higher salinity conditions. Such behavioral ecology is largely consistent with the reconstructed salinity history from $\delta^{18} \mathrm{O}_{\text {otolith }}$ suggesting that the former 2 species may be estuarine resident fishes, whereas the latter may be a marine migrant. The present results also indicated that the use of $\delta^{18} \mathrm{O}_{\text {otolith }}$ for salinity reconstruction is reliable for addressing habitat use patterns and migration ecology of tropical estuarine fishes. Such studies are essential for establishing effective conservation and management policies for estuarine fishes.

Acknowledgements. We are grateful to Ken Sakihara, Akira Mizutani, Takahiro Kanai and Hiroyuki Inoue for assistance with fieldwork. Our thanks also to Noriko Izumoto for $\delta^{18} \mathrm{O}$ measurements of water and calcium carbonate samples, and to Toshihiro Miyajima for allowing the use of water isotopic analysis instruments. We also sincerely appreciate Graham Hardy for the English language review, and Editor-in-Chief Dr. Myron Peck and 3 anonymous reviewers for constructive comments on the manuscript. This study was supported by a Grant-in-Aid for Scientific Research (A) from the Japan Society for the Promotion of Science (no. 26252027), partly supported by a MEXT KAKENHI Grant Number JP15H 05823, JP16KT0028, and the Cooperative Program (no. 112, 2015) of Atmosphere and Ocean Research Institute, The University of Tokyo.

\section{LITERATURE CITED}

Allen GR (1991) Damselfishes of the world. Mergus, Melle Amano Y, Kuwahara M, Takahashi T, Shirai K, Yamane K, Amakawa H, Otake T (2013) Otolith elemental and Sr isotopic composition as a natal tag for Biwa salmon Oncorhynchus masou subsp. in Lake Biwa, Japan. Aquat Biol 19:85-95

Amano Y, Shiao JC, Ishimura T, Yokouchi K, Shirai K (2015) Otolith geochemical analysis for stock discrimination and migratory ecology of tunas. In: Kitagawa $\mathrm{T}$, Kimura $\mathrm{S}$ (eds) Biology and ecology of bluefin tuna. CRC Press, New York, NY, p 225-257

Blaber SJM (2000) Tropical estuarine fishes: ecology, exploitation and conservation. Blackwell Science, Oxford

Bowen GJ (2008) Spatial analysis of the intra-annual variation of precipitation isotope ratios and its climatological corollaries. J Geophys Res 113:D05113

Bowen GJ (2010) Isoscapes: spatial pattern in isotopic biogeochemistry. Annu Rev Earth Planet Sci 38:161-187

*Bogan MW (1994) Distribution and retention of larval fishes near reefs in the Gulf of California. Mar Ecol Prog Ser 115:1-13

*Bown RJ, Severin KP (2009) Otolith chemistry analyses indicate that water $\mathrm{Sr}: \mathrm{Ca}$ is the primary factor influencing otolith $\mathrm{Sr}$ :Ca for freshwater and diadromous fish but not formarine fish. Can J Fish Aquat Sci 66:1790-1808

* Duke NC, Meynecke JO, Dittmann S, Ellison AM and others (2007) A world without mangroves? Science 317:41-42

Elliott M, Whifield AK, Potter IC, Blaber SJM, Cyrus DP, Nordlie FG, Harrison TD (2007) The guild approach to categorizing estuarine fish assemblages: a global review. Fish Fish 8:241-268
Elsdon TS, Gillanders BM (2002) Interactive effects of temperature and salinity on otolith chemistry: challenges for determining environmental histories of fish. Can J Fish Aquat Sci 59:1796-1808

*Elsdon TS, Gillanders BM (2004) Fish otolith chemistry influenced by exposure to multiple environmental variables. J Exp Mar Biol Ecol 313:269-284

Elsdon TS, Wells BK, Campana SE, Gillanders BM, Jones CM, Limburg KE, Walther BD (2008) Otolith chemistry to describe movements and life-history parameters of fishes: hypotheses, assumptions, limitations and inferences. Oceanogr Mar Biol Annu Rev 46:297-330

Feutry P, Tabouret H, Maeda K, Pécheyran C, Keith P (2012) Diadromous life cycle and behavioural plasticity in freshwater and estuarine Kuhliidae species (Teleostei) revealed by otolith microchemistry. Aquat Biol 15:195-204

Fisher R, Bellwood DR, Job SD (2000) Development of swimming abilities in reef fish larvae. Mar Ecol Prog Ser 202:163-173

* Gillanders BM, Munro AR (2012) Hypersaline waters pose new challenges for reconstructing environmental histories of fish based on otolith chemistry. Limnol Oceanogr 57:1136-1148

Godiksen JA, Svenning MA, Dempson JB, Marttila M, Storm-Suke A, Power M (2010) Development of a speciesspecific fractionation equation for Arctic charr (Salvelinus alpinus (L.)): an experimental approach. Hydrobiologia 650:67-77

Høie H, Otterlei E, Folkvord A (2004) Temperaturedependent fractionation of stable oxygen isotopes in otoliths of juvenile cod (Gadus morhua L.). ICES J Mar Sci 61:243-251

Inoue $\mathrm{H}$, Murakami $\mathrm{K}$, Nanjo $\mathrm{K}$, Mizutani A, Kohno $\mathrm{H}$ (2016a) Tidal fluctuation of salinity and distribution of dominant fish species in Udara River, Amitori Bay, Iriomote Island. J Japan Soc Civil Eng, Ser B3 (Ocean Eng) 72:1087-1092 (in Japanese)

Inoue H, Nanjo K, Mizutani A, Kitano T, Kohno H (2016b) Spatiotemporal changes in fish assemblage structures in the Udara River, Amitori Bay, Iriomote Island. Jpn J Ichthyol 63:63-79 (in Japanese)

Ishimura T, Tsunogai U, Gamo T (2004) Stable carbon and oxygen isotopic determination of sub-microgram quantities of $\mathrm{CaCO}_{3}$ to analyze individual foraminiferal shells. Rapid Commun Mass Spectrom 18:2883-2888

* Ishimura T, Tsunogai U, Nakagawa F (2008) Grain-scale heterogeneities in the stable carbon and oxygen isotopic compositions of the international standard calcite materials (NBS 19, NBS 18, IAEA-CO-1, and IAEA-CO-8). Rapid Commun Mass Spectrom 22:1925-1932

Kanai T, Nanjo K, Yamane K, Amano Y, Kohno H, Watanabe Y, Sano M (2014) Utilization patterns of estuarine and marine habitats by the halfbeak Zenarchopterus dunckeri at Iriomote Island, southern Japan, evaluated from otolith microchemistry. Fish Sci 80:1231-1239

Kendall C, Doctor DH (2003) Stable isotope applications in hydrologic studies. In: Holland HD, Turekian KK, Drever JI (eds) Treatise on geochemistry, Vol 5. Elsevier, p 319-364

Kerr LA, Secor DH, Kraus RT (2007) Stable isotope $\left(\delta^{13} \mathrm{C}\right.$ and $\delta^{18} \mathrm{O}$ ) and $\mathrm{Sr} / \mathrm{Ca}$ composition of otoliths as proxies for environmental salinity experienced by an estuarine fish. Mar Ecol Prog Ser 349:245-253

* Kim ST, O'Neil JR, Hillaire-Marcel C, Mucci A (2007a) Oxygen isotope fractionation between synthetic aragonite 
and water: influence of temperature and $\mathrm{Mg}^{2+}$ concentration. Geochim Cosmochim Acta 71:4704-4715

Kim ST, Mucci A, Taylor BE (2007b) Phosphoric acid fractionation factors for calcite and aragonite between 25 and $75^{\circ} \mathrm{C}$ : revisited. Chem Geol 246:135-146

Kimirei IA, Nagelkerken I, Mgaya YD, Huijbers CM (2013) The mangrove nursery paradigm revisited: otolith stable isotopes support nursery-to-reef movements by IndoPacific fishes. PLOS ONE 8:e66320

Kitagawa T, Ishimura T, Uozato R, Shirai K and others (2013) Otolith $\delta^{18} \mathrm{O}$ of Pacific bluefin tuna Thunnus orientalis as an indicator of ambient water temperature. Mar Ecol Prog Ser 481:199-209

Kobayashi DR (1989) Fine-scale distribution of larval fishes: patterns and processes adjacent to coral reefs in Kaneohe Bay, Hawaii. Mar Biol 100:285-293

Kosuge T, Kohno H (2010) Breeding season of the soldier crab, Mictyris brevidactylus (Crustacea, Brachyura, Mictyridae) in Urauchi River, Iriomote Island. Bull Inst Oceanic Res Develop Tokai Univ 31:43-50

Kubota K, Shirai K, Murakami-Sugihara N, Seike K, Hori M, Tanabe K (2017) Annual shell growth pattern of the Stimpson's hard clam Mercenaria stimpsoni as revealed by sclerochronological and oxygen stable isotope measurements. Palaeogeogr Palaeoclimatol Palaeoecol 465: 307-315

* LeGrande AN, Schmidt GA (2006) Global gridded data set of the oxygen isotopic composition in seawater. Geophys Res Lett 33:L12604

Lewis AD, Hogan AE (1987) The enigmatic jungle perch: recent research provides some answers. S Pac Comm Fish Newsl 40:24-31

Loh KH, Cheng YH, Chen HM (2013) The study of reproductive behavior and embryonic developments of Neopomacentrus cyanomos. Malaysian J Sci 32:39-48

Macdonald JI, Crook DA (2010) Variability in Sr:Ca and $\mathrm{Ba}$ :Ca ratios in water and fish otoliths across an estuarine salinity gradient. Mar Ecol Prog Ser 413:147-161

Manson FJ, Loneragan NR, Skilleter GA, Phinn SR (2005) An evaluation of the evidence for linkages between mangroves and fisheries: a synthesis of the literature and identification of research directions. Oceanogr Mar Biol Annu Rev 43:483-513

* McCulloch M, Cappo M, Aumend J, Müller W (2005) Tracing the life history of individual barramundi using laser ablation MC-ICP-MS Sr-isotopic and $\mathrm{Sr} / \mathrm{Ba}$ ratios in otoliths. Mar Freshw Res 56:637-644

Meynecke JO, Lee SY, Duke NC, Warnken J (2007) Relationships between estuarine habitats and coastal fisheries in Queensland, Australia. Bull Mar Sci 80:773-793

Mwandya AW, Gullström M, Öhman MC, Andersson MH, Mgaya YD (2009) Fish assemblages in Tanzanian mangrove creek systems influenced by solar salt farm constructions. Estuar Coast Shelf Sci 82:193-200

* Nagelkerken I, Blaber SJM, Bouillon S, Green P and others (2008) The habitat function of mangroves for terrestrial and marine fauna: a review. Aquat Bot 89:155-185

Nakamura Y, Horinouchi M, Shibuno T, Tanaka Y and others (2008) Evidence of ontogenetic migration from mangroves to coral reefs by black-tail snapper Lutjanus fulvus: a stable isotope approach. Mar Ecol Prog Ser 355:257-266

Nanjo K, Kohno H, Nakamura Y, Horinouchi M, Sano M (2014a) Differences in fish assemblage structure between vegetated and unvegetated microhabitats in rela- tion to food abundance patterns in a mangrove creek. Fish Sci 80:21-41

*Nanjo K, Kohno H, Nakamura Y, Horinouchi M, Sano M (2014b) Effects of mangrove structure on fish distribution patterns and predation risks. J Exp Mar Biol Ecol 461:216-225

Neira FJ (1991) Larval development of the oral brooding cardinalfish Apogon rueppellii (Teleostei: Apogonidae) in Western Australia. Rec West Aust Mus 15:573-584

Nelson JS (2006) Fishes of the world, 4th edn. John Wiley and Sons, Hoboken NJ

* Otake T, Ishii T, Nakahara M, Nakamura R (1997) Changes in otolith strontium: calcium ratios in metamorphosing Conger myrisaster leptocephali. Mar Biol 128:565-572

Patterson WP, Smith GR, Lohmann KC (1993) Continental paleothermometry and seasonality using the isotopic composition of aragonitic otoliths of freshwater fishes. In: Swart PK, Lohmann KC, McKenzie J, Savin S (eds) Climate change in continental isotopic records. Geophysical Monograph 78, American Geophysical Union, Washington DC, p 191-202

Radtke RL, Lenz P, Showers W, Moksness E (1996) Environmental information stored in otoliths: insights from stable isotopes. Mar Biol 127:161-170

Robertson AI, Duke NC (1987) Mangroves as nursery sites: comparisons of the abundance and species composition of fish and crustaceans in mangroves and other nearshore habitats in tropical Australia. Mar Biol 96:193-205

Sakai S (2009) Micromilling and sample recovering techniques using high-precision micromill 'GEOMILL326'. JAMSTEC-Reports, Japan Agency for Marine-Earth Science and Technology, Yokosuka, p 35-38

Sakamoto T, Komatsu K, Yoneda M, Ishimura T and others (2017) Temperature dependence of $\delta^{18} \mathrm{O}$ in otolith of juvenile Japanese sardine: laboratory rearing experiment with micro-scale analysis. Fish Res 194:55-59

* Sheaves M (2016) Simple processes drive unpredictable differences in estuarine fish assemblages: baselines for understanding site-specific ecological and anthropogenic impacts. Estuar Coast Shelf Sci 170:61-69

* Shibuno T, Nakamura Y, Horinouchi M, Sano M (2008) Habitat use patterns of fishes across the mangroveseagrass-coral reef seascape at Ishigaki Island, southern Japan. Ichthyol Res 55:218-237

* Shinnaka T, Sano M, Ikejima K, Tongnunui P, Horinouchi M, Kurokura H (2007) Effects of mangrove deforestation on fish assemblage at Pak Phanang Bay, southern Thailand. Fish Sci 73:862-870

Shirai K, Kawashima T, Sowa K, Watanabe T and others (2008) Minor and trace element incorporation into branching coral Acropora nobilis skeleton. Geochim Cosmochim Acta 72:5386-5400

Shirai K, Otake T, Kuroki M, Ushikubo T and others (2010) Eel larvae may hatch in the surface layer near the West Mariana Ridge: ion microprobe delta O-18 analysis with $7 \mu \mathrm{m}$ spatial resolution in glass eel otoliths. Geochim Cosmochim Acta 74:A955

Shirai K, Otake T, Amano Y, Kuroki M and others (in press) Temperature and depth distribution of Japanese eel eggs estimated using otolith oxygen stable isotopes. Geochim Cosmochim Acta, doi:10.1016/j.gca.2018.03.006

Storm-Suke A, Dempson JB, Reist JD, Power M (2007) A field-derived oxygen isotope fractionation equation for Salvelinus species. Rapid Commun Mass Spectrom 21: 4109-4116 
Sturrock AM, Trueman CN, Darnaude AM, Hunter E (2012) Can otolith elemental chemistry retrospectively track migrations in fully marine fishes? J Fish Biol 81:766-795

Surge DM, Lohmann KC (2002) Temporal and spatial differences in salinity and water chemistry in SW Florida estuaries: effects of human-impacted watersheds. Estuaries Coasts 25:393-408

Tanner SE, Reis-Santos P, Vasconcelos RP, Fonseca VF, França S, Cabral HN, Thorrold SR (2013) Does otolith geochemistry record ambient environmental conditions in a temperate tidal estuary? J Exp Mar Biol Ecol 441:7-15

Thorrold SR, Campana SE, Jones CM, Swart PK (1997) Factors determining $\delta^{13} \mathrm{C}$ and $\delta^{18} \mathrm{O}$ fractionation in aragonitic otoliths of marine fish. Geochim Cosmochim Acta 61:2909-2919

Tsukamoto K, Nakai I, Tesch WV (1998) Do all freshwater eels migrate? Nature 396:635-636

Uemura R, Yonezawa N, Yoshimura K, Asami R, Kadena H, Yamada K, Yoshida N (2012) Factors controlling isotopic composition of precipitation on Okinawa Island, Japan: implications for paleoclimate reconstruction in the East Asian Monsoon region. J Hydrol 475:314-322

Editorial responsibility: Stephen Wing,

Dunedin, New Zealand
Ushie H, Kawahata H, Suzuki A, Murayama S, Inoue M (2010) Enhanced riverine carbon flux from carbonate catchment to the ocean: a comparative hydrogeochemical study on Ishigaki and Iriomote islands, southwestern Japan. J Geophys Res Biogeosci 115:G02017

* Walther BD, Nims MK (2015) Spatiotemporal variation of trace elements and stable isotopes in subtropical estuaries: I. Freshwater endmembers and mixing curves. Estuaries Coasts 38:754-768

* Walther BD, Kingsford MJ, O'Callaghan MD, McCulloch MT (2010) Interactive effects of ontogeny, food ration and temperature on elemental incorporation in otoliths of a coral reef fish. Environ Biol Fishes 89:441-451

Walther BD, Dempster T, Letnic M, McCulloch MT (2011) Movements of diadromous fish in large unregulated tropical rivers inferred from geochemical tracers. PLOS ONE 6:e18351

Whitfield AK (1990) Life-history styles of fishes in South African estuaries. Environ Biol Fishes 28:295-308

K Zimmerman CE (2005) Relationship of otolith strontium-tocalcium ratios and salinity: experimental validation for juvenile salmonids. Can J Fish Aquat Sci 62:88-97

Submitted: April 13, 2017; Accepted: January 23, 2018

Proofs received from author(s): April 3, 2018 